\title{
Predicting the Future Competence Needs in Working Life: Didactical Implications for VET in Norway
}

\author{
Ann Lisa Sylte \\ Oslo Metropolitan University, Faculty of Teacher Education and International Studies, \\ Postboks 4, St. Olavs plass 0130 Oslo, Norway
}

Received: 01.06.2019, Accepted: 14.04.2020, Published: 11.08.2020

\begin{abstract}
Context: Two major challenges in professional and vocational education (VET) are low levels of relevance and coherence between the content of the educational program and developing competence in working life. This article is based on an action research project, conducted as a series of experiments at vocational upper secondary schools and during the basic course for postgraduate certificate teaching in professional education for professional educators in Norway. It was carried out with a focus on job-related professional education to meet these challenges. The project is based on a pragmatic theoretical perspective in professional didactical teaching.
\end{abstract}

Methods: The action research included experiments, observations, evaluations, qualitative questionnaires and interviews.

Findings: The results show empirical examples of didactical principles in job-related professional education; the core of these being the analysis of work tasks and work practice as a basis for curricula analysis and planning of teaching and assessing. This includes job-related planning of content, teaching and assessment according to comprehensive professional competence. The results also show challenges linked to job-related professional education.

Conclusions: The overall results show a need for the development of professional didactical teaching competencies that focus on job-related professional education, to meet the future needs for competence in work life.

${ }^{*}$ Corresponding author: asylte@oslomet.no 
Keyword: Job-Related Professional Competence, Comprehensive Professional Competence, Job-Related Professional Content, Teaching and Assessment, Workplace Learning, Vocational Education and Training, VET

\section{Introduction}

The primary challenge in vocational and professional education (VET) in teacher training programmes is a lack of coherence; a gap between theory and practice, and between education and the need for competence in the workplace (Billet \& Choy, 2013; Hiim, 2017; Sullivan, 2005). This is an important field of research, since VET is often perceived to be irrelevant for the professions it leads to (Billet, 2010, 2014; Hiim, 2016; Smeby, 2015; Sullivan \& Benner, 2005). In Norwegian VET in upper secondary school, there is often disconnect between what is taught in school, and what is practiced in the field/work life (Dahlback et al., 2018). This is at least in part due to the generalised nature of teaching - it does not have a focus on the relevance and professional specialization required in VET (Dahlback et al., 2018; Ministry of Education and Research, 2015-2016). Other examples from VET at the university level are challenges because content in teaching and the assessment methods (for example in nursing and police education), are based on disciplinary theory instead of actual work tasks (Sylte, 2018).

A key teaching target in Norway is that teacher education should involve coherence between theory and practice, teaching subjects and both pedagogical and didactical theory (Ministry of Education and Research, 2008-2009). One consequence of this is that teaching competence is particularly difficult to acquire theoretically. A significant challenge is whether the competence needs of the professions in practice are reflected in the content, teaching and assessment criteria (Hiim, 2016). Therefore, it is essential to focus on didactical principles of relevance in VET to ensure a continuous mastery of professional competence. The main goal of the white paper for VET in Norway is developments that meet future competence needs and coherence in the workplace: "Competence is about acquiring and applying knowledge and skills. It is about learning to cope with challenges and solve problems in both known and unknown contexts and situations" (Ministry of Education and Research, 2015-2016, p. 28 ["author translation"]).

Professional job-related education focuses on job-specific relevance for workplace specific competence, and teacher education within this entails a close coherence between the subjects and the pedagogy and didactics, with the purpose of developing comprehensive professional (teacher) competence (Ministry of Education and Research, 2008-2009).

This article is based on an action research project on the development of relevant VET through a workplace-related approach. The project examines didactical principles in developing relevance on two VET levels: 1) Using action research in VET in upper secondary 
schools (USS) for hairdressing, health care and technical occupations, and 2) in a teacher training programme at a specific teaching institution for assistant/associate professors and professors in nursing, engineering and police education (Sylte, 2014, 2015, 2018). The focus in this article is: Which didactical principles can make VET relevant for future competence requirements in workplaces? The research questions were:

1. How can professional job-relevance content and teaching be managed in VET?

2. How can professional job-relevance assessment be managed in VET?

According to the research questions, the action research included two development experiments (E1, E2). Developments of professional job-related content and teaching methods in VET (E1): In both subprojects, the experiments (E1) involved practical-theoretical learning of didactic relation planning, teaching and assessment, based on an analysis of work tasks and qualification requirements in work life and society (Hiim \& Hippe, 2001). The participants also should analyse the curriculum to see whether it provided room for practical-theoretical student tasks.

Developments of professional job-related assessment methods in VET (E2): In the second experiment, the USS teachers should plan comprehensive student tasks based on work tasks. The participants should develop practical-theoretical assessment methods with characteristics for electrician and hairdressing USS programmes. In subproject 2, the professors also should learn practical theory to develop assessment methods to describe quality characteristics.

The development of didactical knowledge and the principles of relevance involve a professional job-specific focus on content, teaching and assessment methods in VET. This involves didactic planning and the implementation of both teaching and assessment, based on the analysis of work tasks and qualification requirements. Although workplace training is important, this research is limited to developing relevant competence education in schools and universities. In other words, research confirms the problem of relevance, but there are few studies that focus on how we can address this.

Although there are some significant differences in VET at the upper secondary and university level, a central feature is that both levels target specific professions where the workplace is often part of the training arena. The author's experience as a teacher at both the vocational upper secondary school, and within a teacher training programme for professors at the university level has shown that many of the same problems (of relevance and the need for a professional job-related VET) arise in both settings. The need for job-relevant education is seen, for example, in hairdressing education and teacher education. Didactic principles may very well help develop professional judgment at both levels of VET. The problem is that the content is often not perceived as relevant to the profession (Hiim, 2017; Sullivan \& 
Benner, 2005). While it may be considered a problem that this study analyses development experiments in two different educational levels, it is also a strength - identifying examples and practices that may be useful at both levels, as the project assumes that the two levels have similar challenges (those of relating education and training to work life), and may therefore find similar solutions.

Comprehensive professional competence in this article focuses on a holistic competence that includes professional subjects and key competences, such as collaborative ability, independence, creativity and innovative and critical thinking (Sylte, 2018). For instance, a hairdresser requires competence on how to colour and cut hair, customer service, new hair trends, as well as products and environmental changes in society. Comprehensive professional competence also includes an understanding of how a profession is practiced and its function in society, in addition to its culture, traditions and development (Sylte, 2018).

In this article, the term "coherence" stands for coherence between what is taught in school and what is practiced in the field. A lack of coherence can be linked to a gap between theory and practice and subjects in VET. In teacher education, there can be a gap between the curriculum (content), pedagogic theory, and the professional practice in the school (Smeby \& Heggen, 2012).

Didactical principles refer to how teachers undertake practical-theoretical planning, implementation (content and teaching methods) and assessment, and critical analyses of the teaching in VET, in both upper secondary school and university level (Hiim \& Hippe, 2001).

First in this article, the previous research about relevance problem coherence to the future workplace needs for competence, will be described. Then I will focus on the theoretical perspective of didactical principles for relevant VETs. After that, I will describe the method for the project, before the presentation of the main results. At last, I will discuss the articles research issue and bring up some conclusions.

\section{Relevance, VET, and Future Competency Needs in the Workplace}

A great deal of previous research into VET has focused on relevance: Contemporary VET is often not perceived as relevant for the job or profession it is meant to prepare students for. One criticism is that universities have placed too much of an emphasis on analytical and scientific thinking and have only partially succeeded in teaching methods to achieve proficiency and wisdom in complex practical work situations outside the university classroom. The theories taught are characterized by pure academic disciplines and are less focused on experiential knowledge gained through practice (Sullivan \& Benner, 2005).

Work content and rapid developments in society necessitate lifelong learning (Billett, 2010). Society continuously changes; therefore, future competency needs involve more than academic disciplines. Several studies to date have confirmed the effectiveness of work-re- 
levant learning at both levels of VET, which provide a stronger coherence with workplace competence (Canrinus et al., 2015; Haight, 2012; Hiim, 2016; Smeby \& Heggen, 2012). For instance, Loo's (2012) research in teacher education points to positive effects when students have both professional experience and teaching experience prior to undertaking the education. Similar positive effects were found by Loo (2012) when students are working parttime within their profession during their teacher education. The professors in the TTP in the author's second subproject had a similar background as the students in Loo's (2012) study.

A lot of today's debate based on recent research on VET challenges, is about the role of VET in the VET-systems of various nations (Guile \& Unwin, 2019a). There is some recent research about how expertise is developed in an age of considerable transformation in work processes and the future competence needs in working life. Guile and Unwin (2019b) examine many of the challenges of VET such as the need for training in the context of extended working lives and the professional development of vocational teachers. Guile and Unwin (2019b, p. 19) say that "VET has paid a price for becoming overly institutionalized within national education and training systems". They problematize that VET have been "primarily conceptualized, studied, and evaluated through an educational lens" (p. 20). They point to a major challenge that the VET students practice in work life "are framed within the requirements of VET programs and/or professional regulations" (p. 20). Guile and Unwin (2019b) also argue in line with Canrinus et al. (2015) and Smeby and Heggen (2012), that a lack of coherence between VET and concepts and changes in working life and professional competence, the less effective and meaningful VET becomes.

Working life has begun to require other qualities than those currently focused on within a school setting. Wagner's (2008) analysis of future workplace needs of competence identified that what you know means much less than what you can use the knowledge for. Wagner found that the ability to be innovative, to creatively solve problems and to look for new opportunities, as well as skills like critical thinking, communication and collaboration, are much more important than academic knowledge. The need for complex problem solving was also ranked highest by the World Economic Forum's (2018) description of competence needs in the future workplaces. These kinds of competencies are implicated in comprehensive professional competence but are difficult to assess separately from each other through theoretical or practical assessment methods. Baartman et al. (2013) point out the challenge that assessment methods are not often included in Miller's (1990) higher competence levels of show and how/does in assessments.

Assessment methods have shifted the focus from an assessment of learning to an assessment for learning, which involves both formative assessment and self-assessment with a focus on learning (Torrance, 2007). When students are actively involved in the assessment process, both motivation and the learning outcomes are strengthened (Hattie \& Timperley, 2007). However, Baartman et al. (2013) point out that self- and formative assessment are not 
sufficient and question whether professional competence requirements are actually reflected in the assessment criteria. Miller (1990) divides competence assessment into four levels in a pyramid: The lowest is assessment of knowledge, the second knows how, the third is showing how and the highest is doing in a realistic and complex context.

Addressing Miller's structural competence would involve a workplace-related assessment where the student is given the opportunity to show the complexity of the VET role (comprehensive professional competence) (Grollmann, 2008; Sylte, 2018). Gulikers et al. (2017) argue that: "This highest level requires an integration of knowledge, skills and attitudes in competent performance, assuming that competent performance cannot be undertaken if underlying knowledge and skills are not internalised" (p. 4). I am in agreement with this argument because theory is important, but the problem is that assessment at VET mostly implies Miller's levels of knowing and knowing how through written assignments separate from practice, while job-related assessment of comprehensive professional competence requires methods that safeguard all levels of the pyramid in a holistic way.

This is in line with Winch (2010) who points to the importance of that developing expertise requires the integration of "knowing how" and "knowing that". Winch (2010) highlights the need for knowledge that involves not only knowledge of many propositions, but also a mastery of inferential correlation between propositions. It can be about mastering key concepts in the subject and practical knowledge of procedures for acquiring knowledge and testing knowledge requirements. Such comprehensive professional competence often involves "the ability to deploy propositional knowledge in practical procedures, for example, in checking whether a new knowledge claim is consistent with propositions that are already accepted within the subject, for example, in the construction of measuring or testing equipment" (p. 104). At the same time, he emphasizes that a professional also need "an intelligible account of how propositional knowledge in general and deliberately utilized bodies of systematically organized knowledge can bear on practice in judgement" (p. 104).

However, previous research has primarily focused on problems of relevance related to future competence needs for coherence in the workplace, most recently on relevance, coherence and the provision of comprehensive professional competence (Grollmann, 2008; Sylte, 2018). For example, this means that tertiary students in VET must demonstrate the ability to perform teaching and be able to solve complex challenges linked to their assignments or to the practice of their profession. Based on the concept of comprehensive professional competence, VET requires forms of content, teaching and assessment methods than ones that distinguish between theory and practice. According to Guile and Unwin (2019a), VET need to focus on "what is sometimes naively referred to as "the world of work", through to bespoke training organized by or for employers and self-taught activity" (p. 1). Therefore, VET needs "programs that have a specific occupational focus (...), and work-based learning of various types and duration triggered by changes and innovation in work processes" (p. 1). 


\section{Pragmatic Theoretical Perspectives on Didactical Principles: Developing the Workplace Competency Requirements}

The project is based on a pragmatic theoretical perspective in professional didactical relational thinking and learning. Experience and language are both considered processes in which concepts are developed through participation in practical contexts (Hiim, 2017). An important difference between pragmatic versus conventional educational thinking is that the curriculum, content, teaching and assessment are based on work tasks (Dewey, 1895, 1972; Dreyfus \& Dreyfus, 1986; Hiim, 2017; Schön, 1983). The focus is on the development of comprehensive professional competencies, rather than context-free abstract theory. A pragmatic theoretical perspective also includes teacher planning, teaching and assessment related to profession-based work tasks in coherence to the relation model of didactics. This model contains the didactical categories of goals, resources/frames, cont $\neg$ ent, learning process, assessment and learning condition, as illustrated in Figure 1 (Hiim \& Hippe, 2001; Sylte, 2016).

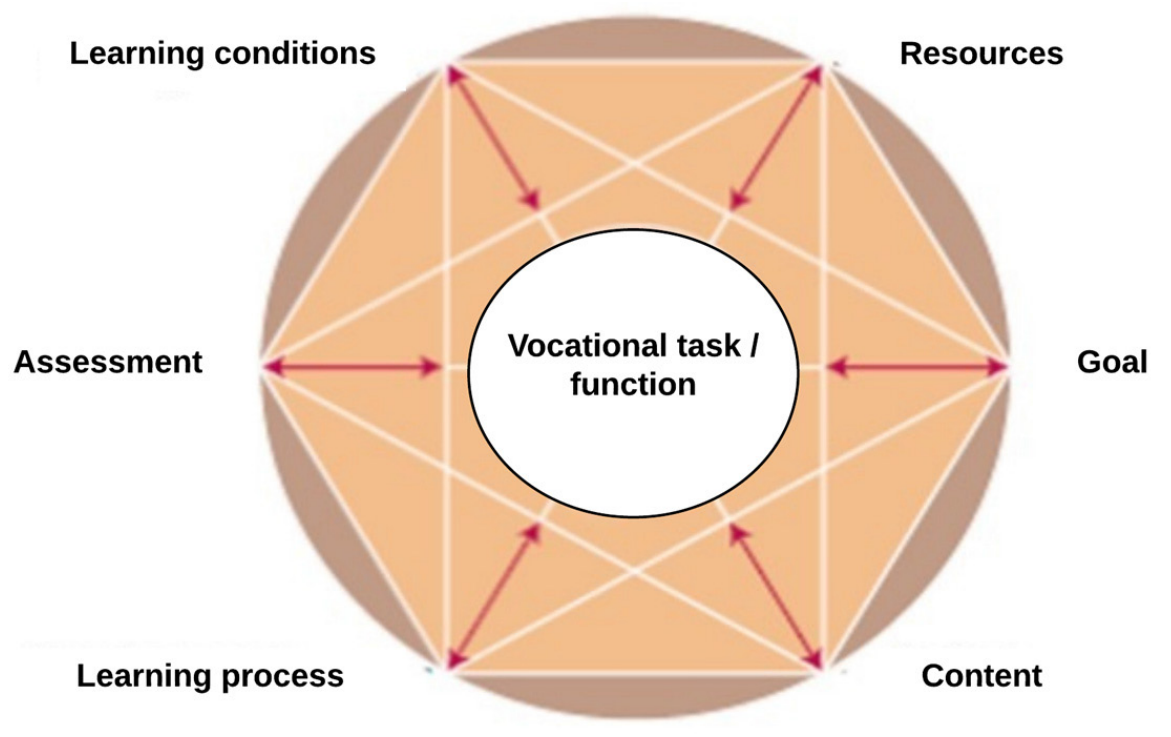

Figure 1: The Relation Model of Didactics (Sylte, 2016, p. 52; Hiim \& Hippe, 2001, p. 32)

The model above illustrates how these categories influence each other and are mutually dependent. For instance, if the student's learning conditions for a work task are lower than first assumed, this will influence the learning objectives of the lecture, as well as the other categories. This is because the learning process, assessment and other categories must be adapted to the students' learning conditions, while still ensuring that the overall learning ob- 
jectives are covered. It is important that learning happens by interacting and reflecting over the experiences gained through the work tasks - a reflection both in and on action (Schön, 1983). According to a work process, you may make changes, adjustments and corrections along the way. Thoughts and actions are part of a holistic process. Reflection-on-action means that the practitioner thinks and reflects more consciously after the action is performed, comparing and assessing alternative actions. According to Schön, individuals also need professional discretion to solve work tasks, which requires both practical theoretical knowledge and practical experience. Schön claims that the professional knowledge lies in action, and that professional practice is dependent upon knowledge-in-action. In addition, according to Dreyfus and Dreyfus (1986), there is a need for expert competence in which the student can use theory and practice to solve work problems and tasks. An expert competence also includes skills in how to learn - lifelong learning (Billet, 2010).

In summary, Dewey $(1895,1972)$ emphasizes experimental problem solving, experience and reflection in the learning process. Key competencies such as accountability and accuracy often include tacit knowledge, which must be learned through conscious reflection both in and on action (Schön, 1983). Schön's "reflection in and on action" is identified as a central didactic principle, which is important to emphasize in assessment methods by characteristics of low, medium and high levels of quality. Another important didactical principle is that assessment must be linked to professional context and comprehensive professional competencies. The goal of relevant VET should be to develop comprehensive professional competence, in which there is discretion, wisdom and judgment. An important didactic principle then becomes that VET should aim to develop an incipient expert competence (Dreyfus \& Dreyfus, 1986; Sylte, 2018) relevant within working life. At the same time, VET must also contribute to the development of students through the formation and development of individual judgment skills. Following Dewey $(1895,1972)$, there is a central didactical principle in which experience is linked to learning processes and formative assessment - especially with regard to the assessment of comprehensive professional competence.

\section{Action Research}

The research approach was pedagogical action research based on two subprojects in VET, inspired by the British tradition of educational action research (Hiim, 2010; McNiff, 2014; Stenhouse, 1975). It is anchored in a pragmatic epistemological perspective based on a pragmatic and critical analysis of teachers' professional knowledge (Hiim, 2010). Education has both a fundamental subjective values-based aspect and a normative, democratic aspect, meaning that the technological "implementation" of predetermined theoretical principles is not possible without understanding these fundamental aspects (Hiim, 2010; McNiff, 2014; Reason \& Bradbury, 2008). The pedagogical action research is based on the main principles of 
the pedagogical action research that has its roots from Lewin (1952). The starting point for educational action research, which originated mainly from the UK in the 1960s and 1970s, has been criticism from teachers who have seen conventional social research as instrumental, and that there was a great gap between research-based knowledge and real life in the classroom (Elliot, 1991; Hiim, 2010; Stenhouse, 1975). The project had a pragmatic research design with inspiration from Australian action research that highlights the power relationships in educational traditions and systems, and where democratic participation among all participants in the research is central (Carr \& Kemmis, 2005; Kemmis, 2010). Knowledge was developed along the way through quality development, as included development experiments as a result of experience inspired by the Bath tradition, which places emphasis on developing science with experience qualities (Sylte, 2015).

The choice of action research is related to the author's understanding of the concept of learning and knowledge. The author has a pragmatic and critical perspective on teacher research and teacher knowledge, which influenced the choice of research method in the project. The author wanted to know how VET could be developed through the participating teachers' specific experiences and reflections on their own practice. The purpose was not to define definitive solutions or procedures, but to describe and analyse empirical examples that showed how relevant VET can be developed and which didactical principles distinguished themselves / were positively identified.

\section{The Development Experiments in the Action Research Subprojects}

The first subproject involved participants (VET teachers) from USS in who were also students at a pedagogical development programme. The second subproject involved participants (professors) who were also students in a teacher training programme for professors (TTP) in VET educations at the university (Figure 2). The author was an action researcher, teaching in both programmes. 


\begin{tabular}{|c|c|c|c|c|}
\hline \multirow{2}{*}{\multicolumn{2}{|c|}{$\begin{array}{l}\text { The Action Research Project's } \\
\text { Research Questions (RQ): } \\
\text { RQ1: How can professional job-relevance } \\
\text { content and teaching be managed in VET? }\end{array}$}} & \multicolumn{3}{|c|}{$\begin{array}{l}\text { The two Delevopment Experiments in the Action } \\
\text { Research (E1 \& E2): }\end{array}$} \\
\hline & & \multicolumn{3}{|c|}{$\begin{array}{l}\text { E1: Developments of professional job-related content and } \\
\text { teaching methods in VET }\end{array}$} \\
\hline \multicolumn{2}{|c|}{$\begin{array}{l}\text { RQ2: How can professional job-relevance } \\
\text { assessment be managed in VET? }\end{array}$} & \multicolumn{3}{|c|}{$\begin{array}{l}\text { E2: Developments of professional job-related assessment me- } \\
\text { thods in VET }\end{array}$} \\
\hline $\begin{array}{l}\text { Action Research } \\
\text { Project: }\end{array}$ & Participants (99): & Participants Teach: & Participants' Role: & Researcher's Role: \\
\hline $\begin{array}{l}\text { Subproject } 1 \text { in upper } \\
\text { secondary school } \\
\text { (USS), 2007-2011, } \\
\text { RQ } 1 \& 2 \\
\text { Experience and } \\
\text { learning from } \\
\text { subproject } 1 \\
\text { influences } \\
\text { Subproject } 2 \text { in a } \\
\text { teacher-training } \\
\text { programme for } \\
\text { professors (TTP), } \\
\text { 2012-2015, RQ } 1 \text { \& } 2\end{array}$ & $\begin{array}{l}37 \text { VET teachers } \\
\text { (USS) were also } \\
\text { students at a peda- } \\
\text { gogical programme } \\
\text { (PDP) at the univer- } \\
\text { sity } \\
62 \text { students at TTP } \\
\text { were also professors } \\
\text { in psychology, law, } \\
\text { veterinary medicine, } \\
\text { police work, } \\
\text { engineering, etc. }\end{array}$ & $\begin{array}{l}6 \text { educational } \\
\text { programmes, which } \\
\text { led to different } \\
\text { vocations (e.g., hair- } \\
\text { dressing, electrician, } \\
\text { health care education } \\
\text { programmes) in } 13 \\
\text { upper secondary } \\
\text { schools } \\
24 \text { different VET } \\
\text { educations at the } \\
\text { university, such } \\
\text { as, e.g., nursing, } \\
\text { veterinary medicine, } \\
\text { engineering, police } \\
\text { education }\end{array}$ & $\begin{array}{l}37 \text { VET teachers } \\
\text { conducted } 20 \\
\text { pedagogical/didactical } \\
\text { development } \\
\text { experiments in USS. } \\
16 \text { E1 and } 4 \text { E2 are the } \\
\text { basis of this article. } \\
\text { TTP students/ } \\
\text { professors } \\
\text { conducted fice } \\
\text { didactical } \\
\text { development- } \\
\text { experiments. } \\
\text { Those five examples } \\
\text { from E1 nursing, } \\
\text { veterinary medicine, } \\
\text { engineering and police } \\
\text { education are the basis } \\
\text { of this article. }\end{array}$ & $\begin{array}{l}\text { - teach at PDP } \\
\text { - action research } \\
\text { - supervised the } \\
\text { participants'/ } \\
\text { teachers' twenty } \\
\text { development } \\
\text { experiments (sixteen } \\
\text { E1 and four E2) in } \\
\text { participants' practice. } \\
\text { - teach and supervised } \\
\text { at TTP } \\
\text { - action research } \\
\text { (four E1 and four E2) } \\
\text { development } \\
\text { experiments in } \\
\text { researcher's own } \\
\text { practice at TTP } \\
\text { (University). } \\
\text { - supervised the pro- } \\
\text { fessors' five E1 deve- } \\
\text { lopment experiments. } \\
\text { teach and supervised } \\
\text { at TTP } \\
\text { - action research } \\
\text { (four E1 and four E2) } \\
\text { development } \\
\text { experiments in } \\
\text { researcher's own } \\
\text { practice at TTP } \\
\text { (University). } \\
\text { - supervised the } \\
\text { professors' five E1 } \\
\text { development } \\
\text { experiments. }\end{array}$ \\
\hline
\end{tabular}

Figure 2: Demographic Information on the Participants and the

Development Experiments in the Action Research Process

To answer the research questions in Figure 2, development experiments (E1 and E2) were carried out through planning, implementation and the evaluation of professional job-related content, teaching and assessment methods, first in the first subproject. Based on the learning and experiences surrounding relevance in the first subproject, the author saw the need to make similar developments in the second subproject. The development processes were documented using logs, reports and surveys, and supplemented with interviews in both the subprojects (Figure 4). 


\section{The Action Process - Background for Empirical Data}

A process model was used in the action research (Figure 3). The development experiments were structured in three or four sequences, illustrated in Figure 3.

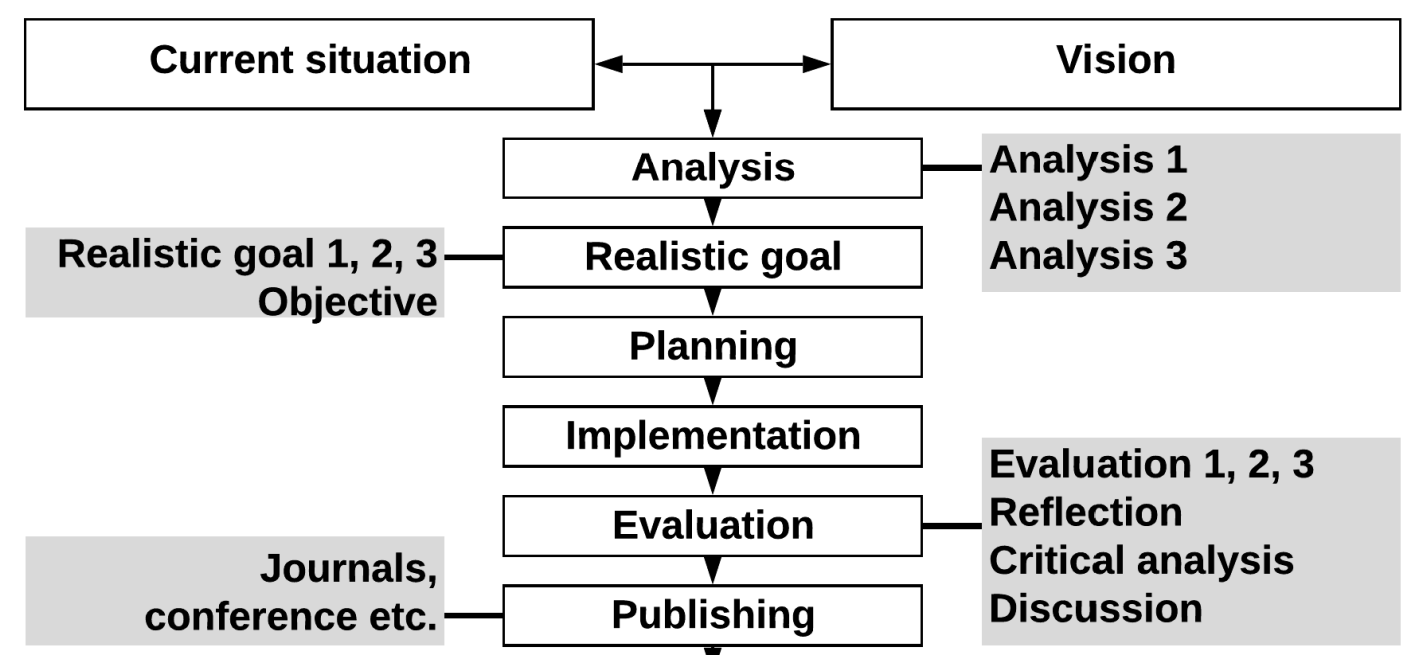

Figure 3: Process Model (Sylte, 2016, p. 237)

In the first subproject the USS teachers analysed and described their current situation, their vision and the objectives for development in their schools. Together with the author, they then planned, implicated and evaluated the experiments, E1 and E2, in three sequences in three different student groups in their own practice. Sixteen USS teachers conducted E1 and four undertook E2. Experiences and learning from the first subproject influenced the second, with the same experiments (E1 and E2) conducted by the researcher. No control group was used as the focus was educational development in VET. In the second subproject, the researcher planned, implemented and evaluated the same E1 and E2 in four sequences in four different student groups (TTP students/professors) in the researcher's practice. In addition, five TTP students/professors conducted experiment E1 in their own teaching practice. The teachers/professors and the author then conducted research in their own practice: "Teacher researchers are uniquely positioned to provide an insider's view that makes visible the way that students and teachers together construct knowledge (...)" (Cochran-Smith \& Lytle, 1993, p. 43).

In the research strategy, it was emphasized that education and research should take place as a comprehensive process. The change process was developed as a collaborative, democratic action, in that the planning, implementation and critical analysis of teaching and learning 
were structured as circular, sequential processes. Data from each sequence therefore became important for what was chosen to proceed in the next sequence.

The empirical data were based on the interactions in the action process and the qualitative data, illustrated in Figure 4. The survey questions and the semi-structured interviews (Patton, 2015) had a focus on how the participants/informants experienced the professional job-relevance content, teaching and assessment methods.

\section{$7 \quad$ Analysis}

In the project, the researcher used Reason and Bradbury's (2008) criteria for validity, the first-, second- and third-person levels of practice. At the first level, participants' research and documentation with empirical descriptions could be processed and systematized in relation to the project's theoretical framework. At the second level, follow-up, guidance, interaction and critical reflection between researchers and participants was important. At the third level, researchers facilitated the participants' investigations or trials. Here, it was also important to compare different participant documentation from a third-person level practice.

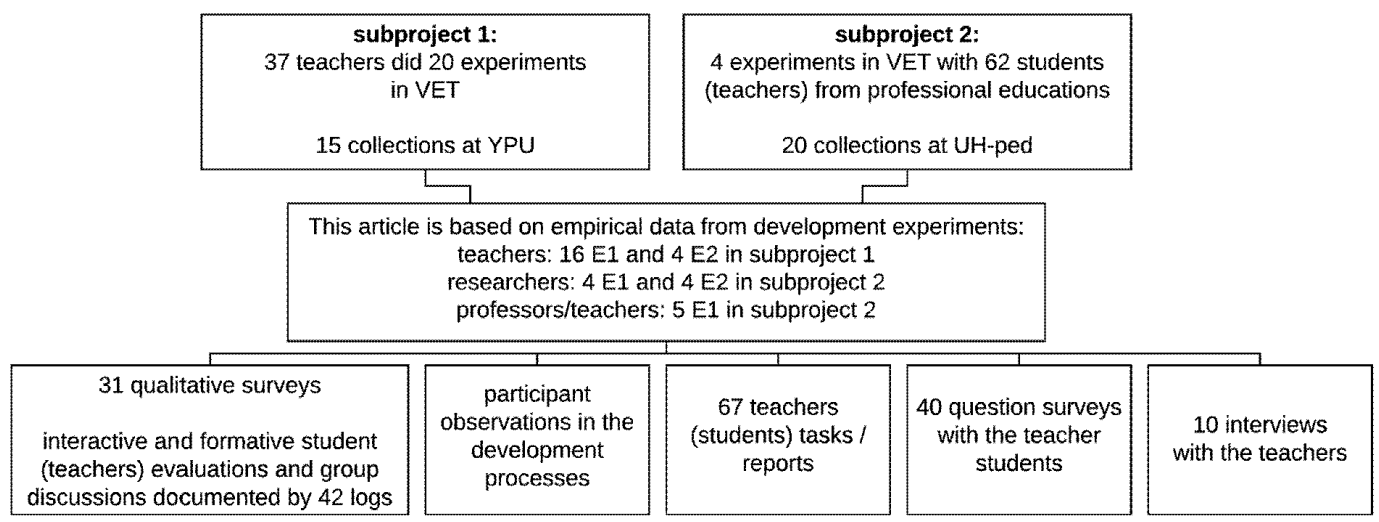

Figure 4: Empirical Data

The critical systematic analysis included discussion and reflection, testing and new actions with new trials, evaluation, discussion, reflection and changing in line with Reason and Bradbury`s (2008) criteria for validity in action research. Based on a pragmatic theoretical perspective, the participants' experiences of relevance and the empirical data (Figure 4) were analysed through coding and categorization of content, teaching methods and assessment. Subcategories that emerged were the opportunities and challenges that related to experiences of professional job-related education among participants and students. In order to avoid being sovereign in the selection of empirical examples, participants were given the opportu- 
nity to proofread the transcription of the interviews and help correct the researcher's interpretation. In both subprojects, the researcher was not looking for generalizable results, but instead empirical examples that others could learn from (McNiff, 2014).

\section{Ethical Considerations}

Credible documentation of the participants' experiences so that analysis of data showed participants' practice was emphasized in the project. Grimen (2004) has criticized the action research approach for giving too much leeway to the researcher's judgment and ability to evaluate. We attempted to accommodate Grimen's criticism by discussing and reflecting critically in a dialogue with the participants about their experiences with the development experiments (Reason \& Bradbury, 2008). Sorting and categorization of data, identification of standards for assessments and bringing forth pattern and evidence, was important for the validity and the ethical considerations. One way to ensure that what the participants had said and experienced, was that the participants had to read the author's analysis with the opportunity to correct. Likewise, I was conscious of my research role as teacher educator and sought to retain a certain amount of professional distance, to limit my subjectivity influencing the analysis.

\section{Results and Discussion}

The USS teachers conducted development experiments with professional job-related content and teaching in their workplaces. One example of a practical-theoretical task is customer care in hairdressing: Based on goals for the programme, the students created individual goals related to a work task, such as haircutting or hair colouring. It was important that the students learned customer care linked to haircutting or colouring as a comprehensive customer treatment in an authentic workplace. Such a practical-theoretical task involves sequences with theory in psychology, communication, hairdressing and hair-colour chemistry (among others). It also involves a forward-looking formative assessment, in which the students reflected on how to solve a hair-colouring problem (Schön, 1983). After practice, the students shared their experiences through plenary presentations. This also involved self-assessment with reflection on knowing how, showing how and doing in a realistic and complex context (Miller, 1990; Schön, 1983). The USS teacher said: "The students liked this teaching method. The students said they were more motivated by solving hair-colouring problems, and they learned how to do and understood why, both for hair colouring and customer care." Similar job-relevant content and teaching methods were also developed in other educational programmes in both the subprojects.

However, teachers noted that in VET programmes in USS, cooperation with the practice field was not used often enough. The results provided examples of how a professional job- 
related education could be conducted in both joint general subjects and professional subject programmes in USS. For example, one USS teacher taught mathematics at a building construction site instead of the classroom and said: "During practical work in the building hall, the students read and interpreted building drawings and integrated mathematics in their own work." Consequently, the students did not experience the theory/mathematic as being difficult. Several of the students improved their grades in the mathematical subjects they had previously failed in secondary school, said the teacher.

The professors experienced that the didactical learning in the development experiment (E1) was useful and relevant: "I have been more aware of planning my teaching, related to work tasks and the curriculum" (professor statement). Five of the professors also conducted similar teaching experiments in their own teaching practice. While learning to plan and conduct police questioning, police students used various theories from law, psychology and sociology. Student nurses learned theory on hygiene related to practical exercises with intramuscular injection procedures. In these examples, theoretical content was taught and learned through a hands-on practical task (Dewey, 1895, 1972). Professional job-related content, teaching and assessment were not common practice for the professors before the training programme, they said. Even though the professors had similar positive backgrounds as described by Loo (2012) which he emphasizes as a positive effect for learning, professional experience and teaching experience prior to undertaking the TTP, and working part-time within their profession during their TTP, it wasn 't enough to teach job-related. The professors were not used to analyses the work tasks and the curriculum as a basis for achieving comprehensive professional competence. Biesta (2014) however argues for the need for coherence between knowledge and curriculum, noting that it is required in order to explain Dewey`s $(1895,1972)$ transaction theory of the pragmatic perspective of learning; including experimental learning such as we undertook in the experiments.

In the second action sequence subproject 2 in TTP, the professors and researcher saw the need for more student involvement and shared job-focused activity. We chose to use a Flipped Classroom (FC) approach to encourage professional job-relevant learning. This implied home preparation of video clips, reading articles and tasks with a description of a challenging teaching situation. In the classroom, the time was used for job-related activities, such as presenting articles with peer assessment, collaborative learning and counselling exercises by reflection on the professors' teaching challenges with their own students (Schön, 1983). The focus was on learning job-related education in VET. "(...) presenting articles has given the most learning", said one of the professors, with another at a veterinary medicine programme saying: "We learn and receive feedback in a real context."

One example of the professors who learned to develop professional job relevance in their own teaching practice were engineering students who solved practical IT problems. Home preparation could be video clips with technical models with theoretical explanations, litera- 
ture/assignments/case studies/problems. In the classroom, there was a joint discussion and solution to the "problems" through plenary and group discussions. One of the professors' students said: "The increased activity of practical exercises with guidance gives me a greater education than the traditional lecture method." The engineering students also conducted an immediate peer assessment of each other's work, while the assessed students still had to focus on their tasks. The FC, the professional job-related approach and the peer-assessment yielded higher learning outcomes, said the professor.

Another professor from a nursing programme conducted a similar teaching in their practice: Nursing students received an animated web lecture on stroke as home preparation for the classroom and repetition. The animation involved drawing and explaining the primary cause mechanisms of stroke. At the end of the animation, a case study created a starting point for dialogue and reflection on practices around stroke in the classroom. The professor noted that "this has led to much greater involvement, motivation and better results", and: "High failure rates were the reason we started with this method and they have gone down ". The professor from the engineering programme also stated that "the average grade has increased from 3.60 to 4.52 ". However, the participants also saw challenges with too much FC, with one professor stating: "Web education is often too monotonous for students to watch".

The results showed a broad scope for job-related education curriculum creation, although some programmes, special health-care programmes, are more knowledge- than competencybased in USS. The same challenges with knowledge-based curriculum in VET can be found at the university level, particularly in health-care programmes. According to the teachers and professors however, a competency-based curriculum gave good opportunities for job relevance.

\section{Comprehensive Professional Competencies}

Findings from the two VET levels show that disciplinary theoretical knowledge is perceived to be of little relevance for the future needs for workplace competence. At the same time, theoretical knowledge in VET is important, when relevant for the work life. One professor said that students perceived pure lectures with an emphasis on discipline-based theoretical knowledge as irrelevant. When participating teachers and professors changed their educational content and teaching methods to suit changes in the future workplace, "it [was] clear that these student-based methods, where they solve challenges and work problems (...) instead of teachers who have a pure lecture on the subject, have led to much greater commitment, motivation and better results" (professor statement). In USS, teachers also said that student practice in cooperation with the workplaces was also necessary to meet the future workplace competency needs (Billett, 2014). These examples show how practical-theoretical knowledge 
can help to develop a comprehensive professional competence that also involves changing skills for rapidly changing workplaces (Wagner, 2008).

The examples from hairdressing, police questioning and nurse injection procedures demonstrate the pedagogical potential of using work tasks as a way to connect practical and theoretical knowledge in educational programmes. In these examples, it was important that the teachers/professors and their students learned reflection in and on action (Schön, 1983). Here, both practical-theoretical knowledge and discretion are used, implying wisdom and good judgment (Dewey, 1895, 1972; Schön, 1983).

However, the result also shows challenges with knowledge-based curricula to promote relevant VET." (...) the curriculum mostly asks for theoretical knowledge", said a professor during an analysis of the curriculum for planning teaching with focus on comprehensive professional competence. This was a challenge on both VET levels, especially for the health-care programme at the USS level and across the board at the university level, where participants saw the need for a more competence-based curriculum in line with workplace needs for competence and pragmatic theory (Dewey, 1895, 1972; Hiim, 2017).

Dewey $(1895,1972)$, Dreyfus and Dreyfus (1986) and Schön (1983) argue that the professional practice of a work task requires professional judgment, practical theoretical knowledge and practical experience. As an example, an electrician-teacher in USS said when students learned through comprehensive work tasks: "(...) that's the way it happens in the real world, in the workplace". However, the question remains of whether it is the teacher's knowledge, perspective or education traditions that may be the reason why some teachers do not undertake job-related content within the education, or see the possibility of it. Many participants felt that some teacher colleagues were not concerned with job-relevant learning at both VET levels.

The results show that coherence as connection between content, teaching and work tasks is a necessary didactic principle (Billet \& Choy, 2013; Canrinus et al., 2015; Hiim, 2016; Smeby \& Heggen, 2012; Sullivan, 2005). "Many of the students have gained motivation (...)", said one of the USS health-care teachers. These students felt relevance when for example, a theory of psychology was used to understand a practical health-care task by reflection. This can be linked to the term knowledge-in-action (Schön, 1983). In nursing education, the professor changed their teaching style from theoretical lectures to student- and job-related issues, in which the students worked on practical tasks, due to earlier problems with high failure rates: "Now the students work with things they wonder about in the classroom", said the professor, and "(...) both motivation and learning outcomes increased."

Student learning related to context, experience and problem-based teaching did help to promote relevance. The professors and their students also both thought that Flipped Classroom was suitable for in the classroom environment, with one student saying: "Different teaching methods and variety are important." However, the most important factor was that 
FC provided an opportunity for job-relevant professional tasks in the classroom, with most students saying it was like using "education to solve/calculate tasks/use computer programmes that are more like something you would do in working life instead of just listening to a lecturer all the time." FC is a valuable addition that provides space for job-related professional practice, but FC as a method alone does not promote relevance. Despite all these factors, VET can be well-created regardless of whether the students hear a lecture before they enter the classroom. It depends on whether the teachers/professors can relate education to the students' professional duties and practice. In our study, both participants and students expressed the need for traditional lectures. However, professional didactics cannot become a simple recipe for how to professionalize the education but must remain didactic principles central to relevant professional education (Sylte, 2018).

The job-relevant teaching methods were perceived by participants and students as meaningful and relevant on both levels: "Many of the students have gained motivation" (USS teacher statement). In addition, the USS teachers discovered that cooperation with the workplace, during internships for instance, was necessary for promoting professional job-related education.

Figure 5 shows three examples of characteristics linked to a practical-theoretical task in customer services in different professions, one in an electrician work task and one in haircutting. The characteristics were based on an analysis of work tasks linked to curriculum analysis. The characteristics described a low, medium and high quality of achievement, such as showing in a realistic and complex context (Miller, 1990; Wagner, 2008). In that way, comprehensive professional competence was emphasized in the characteristics. This assessment method also included self-assessment, formative assessment as a forward-looking statement and a summative assessment of students' practical-theoretical assignments (Baartman et al., 2013; Hattie \& Timperley, 2007; Torrance, 2007).

The characteristics were quality descriptions of achievement levels, which included key competences such as accuracy and accountability. The USS teachers experienced that the students learned how to carry out a work assignment at the same time as they learned the characteristics of high quality in their line of work: "Learning outcomes have increased a lot, because students understand the tasks and what is needed to get high quality in work tasks" (hairdressing teacher statement). Comprehensive professional competence, self-assessment 


\begin{tabular}{|c|c|c|}
\hline \multicolumn{3}{|c|}{ Competence Characteristics in Customer Service } \\
\hline High Level of Achievement & Medium Level of Achievement & Low Level of Achievement \\
\hline $\begin{array}{l}\text { Shows independence by con- } \\
\text { sidering, reflecting on and jus- } \\
\text { tifying key elements that cha- } \\
\text { racterize good customer care, } \\
\text { what customer care entails as } \\
\text { good service and what good } \\
\text { service is, and shows practical } \\
\text { examples of how to provide } \\
\text { such service in a realistic and } \\
\text { complex context }\end{array}$ & $\begin{array}{l}\text { Shows knowledge of good cus- } \\
\text { tomer care, what customer care } \\
\text { entails as good service, what } \\
\text { good service is, and shows } \\
\text { practical examples of how to } \\
\text { provide such service }\end{array}$ & $\begin{array}{l}\text { Describes knowledge of good } \\
\text { customer care and good service }\end{array}$ \\
\hline \multicolumn{3}{|c|}{ Competence Characteristics in Hairdressing - Haircut } \\
\hline High Level of Achievement & Medium Level of Achievement & Low Level of Achievement \\
\hline $\begin{array}{l}\text { The student plans, assembles } \\
\text { and documents air and cable } \\
\text { entry for houses. } \\
\text { The student shows accurancy } \\
\text { and accountability in the } \\
\text { implementation of an electric } \\
\text { energy system. } \\
\text { The student discusses different } \\
\text { solutions and justifies the } \\
\text { choice of method for the work } \\
\text { task. } \\
\text { The student shows practical } \\
\text { examples and good customer } \\
\text { service in a realistic and } \\
\text { complex context. }\end{array}$ & $\begin{array}{l}\text { The student plans, partly } \\
\text { assembles and partly } \\
\text { documents air and cable entry } \\
\text { for houses. } \\
\text { The student shows partial } \\
\text { accurancy and accountability } \\
\text { in the implementation of an } \\
\text { electric } \\
\text { energy system. } \\
\text { The student shows knowledge } \\
\text { of the work task. } \\
\text { The student justifes the choice } \\
\text { of method. } \\
\text { The student shows a simple } \\
\text { assembly and medium } \\
\text { customer care on a customer. }\end{array}$ & $\begin{array}{l}\text { The student mentions some } \\
\text { knowledge of the electric } \\
\text { energy system. } \\
\text { The student shows low medium } \\
\text { accurancy and accountability } \\
\text { in the work task. } \\
\text { The student mentions } \\
\text { knowledge about customer } \\
\text { care, but does not show it in } \\
\text { practice. }\end{array}$ \\
\hline
\end{tabular}

Figure 5: Competence Characteristics

by reflecting in action, and the teachers' forward focused formative assessment was emphasized (Hattie \& Timperley, 2007; Schön, 1983; Torrance, 2007). USS teachers' students found that these methods contributed to increased motivation, learning and professional relevance: "The learning outcomes have increased a lot, (...), through their self-assessment and the teachers' formative assessment with forward looking linked to the characteristics that describe the quality" (hairdressing-teacher statement). 
In subproject 2, the professors also learned practical theory to develop assessment methods to describe quality characteristics. In addition, they learned via training in how assessment related to comprehensive professional qualifications (based on an analysis of work tasks and curriculum), could be used in their own professional workplaces. The results indicated that participants experienced job-relevant assessment methods with an emphasis on comprehensive professional competence as useful and relevant on both levels. Several professors said something along the lines of: "This gave tips and concrete examples of challenges and how these can be solved." However, several participants also experienced challenges with analysing the curriculum in relation to the assessment methods at both levels: "It is difficult to assess comprehensive professional competence when the curriculum is predominantly theoretically based, with a lack of practical context" (professor statement). Ultimately, none of the professors saw the possibility of attempting assessment with these characteristics in their own education, even though they experienced this assessment method as very useful and relevant.

According to the participants at both levels, there are challenges both in the curricula, and because assessment is "locked" in structural terms.

Do the students have a possibility to demonstrate their comprehensive professional competence in the exam? Or does the exam focus mostly on a fragmented theoretical knowledge that the students must memorize without understanding the consequences of the knowledge in practice?

asked one professor who taught nursing education. The challenge of whether comprehensive professional competence is reflected in the assessment methods remains (Baartman et al., 2013). For example, one of the professor's nursing students got a $B$ on her exam, although one of the exam answers was answered so incorrectly that in a real life setting it would have killed the student's patient. The exam consisted of many theoretical questions, which were scored and summarized, providing points that were calculated to make the final exam grade. However, for one of the questions, the consequences would have been grave in practice. Because the student responded perfectly to the other questions, the professor could not give a lower grade than a B, despite giving the wrong answer to such a vital question. This was a common exam form within nursing education.

Participants from both levels also experienced challenges in interpreting curricula, and with assessment regulations for comprehensive professional competence. USS electricianteachers who also developed examples of assessment methods focusing on comprehensive professional competence, discovered that the assessment was closely related to teaching, and said: "We have had almost an 'aha experience' and learned so much, we need to rebuild our entire teaching and think about more comprehensive work assignments in order to ensure relevance." 


\section{Assessment of Comprehensive Professional Competencies}

In working life, assessments and decisions are made without the practitioner always explaining the rules, procedures or theories used (Schön, 1983). According to Schön, this is partly because a lot of professional knowledge cannot be expressed in words - it can only be expressed through practice and reflection in action. It is difficult to explain the quality of a hair colouring, or how to make an intramuscular injection. Schön is further concerned that theoretical reasoning should preferably be linked to different contexts. If not, there is a danger that students only learn " standard answers" and will be unable to exercise judgment in each situation. It is time to ask what type of competence is being asked for in the assessment work in VET (Baartman et al., 2013). Are exams and tests asking for discipline-based and theoretical knowledge, or comprehensive professional competence? Comprehensive professional competence involves various components, such as social, professional and key competencies related to practical skills (Sylte, 2014).

Results from VET in both hairdressing and electrical programmes show that a professional job-related assessment with characteristics of quality is necessary to ensure coherence between the content, teaching and assessment. Although relevant assessment methods are important in VET, many participants experienced challenges because current assessment methods were still theoretical knowledge-focused. The participants also argued that some teaching colleagues seemed more concerned with their own subject area than professional job-related teaching and assessment: "The culture creates challenges for the assessment of comprehensive professional-competencies", said one of the professors.

At an incipient expert level, students distinguish between different situations that require different actions. They can assess the situation and act more intuitively in terms of theoretical understanding, discretion and practical experience (Dreyfus \& Dreyfus, 1986). The students are then no longer bound by the rules of practice but know how to do the appropriate action without making calculations and comparing alternatives. The hairdressing students were aware of what was needed to attain a high level of achievement through the formative and characteristic assessment, with several developing an incipient expert competence (Dreyfus \& Dreyfus, 1986; Hattie \& Timperley, 2007; Torrance, 2007). Yet the nursing student still got a B on the exam, although their comprehensive professional competence was probably at a much lower level. This can be seen in the context of Winch (2010) who points to the importance that students develop competence which involves both "knowing how" and "knowing that". At the same time, the teacher from the USS electrician programme, who had earlier experienced that they had more focus on theoretical knowledge, was now rethinking his approach: "(...) we must actually change our entire teaching and think more comprehensive (...)." This implies that the student assesses and understands the consequences of the knowledge related to the quality of the entire work task. 


\section{Didactical Principles for Promoting the Future Work Life Needs for Competence in VET}

In both subprojects, the participants also experienced challenges with professional didactical competence for professional job-related education: "(...) the biggest obstacle to change the teaching (...) lies with teachers" (professor statement). Much of the argument among VET teachers/professors from both levels of teaching deductively, with the dissemination of theoretical and disciplinary knowledge as a guideline for practice, was the fear of professional impoverishment. Therefore, teaching without coherence to the work tasks and exercises that students experience in today's education will not be sufficient to meet workplace requirements for competence (Billett, 2010). The participants in this research became aware of the importance of work tasks as a starting point for didactic planning, implementation and assessment. This in turn helped promote quality in the students' practical actions, cf. the results from the assessment with characteristics.

However, for teachers/professors who do not see the need for professional job-related education, one possible explanation may be that professional job-related education is perceived as having a unilateral focus on the specific workplace. Young (2004) is critical to a onesided emphasis on workplace competency deciding the focus of VET and worries that the result of such a unilateral focus may be less development of the theoretical aspects within VET. Hoskin and Anderson-Gough (2004) also point to challenges with one-sided work-based learning, because the students also need qualification-focused learning. Their research shows a need for context-based learning; a combination of work-based learning and job-relevant theory is necessary to become a successful professional. Our research results indicate that education must be relevant to both the workplace and the social mandate of the profession. This does not mean that the VET should be theoretical or characterized by a narrow and instrumental theory of comprehension - instead, it means that the theory should illuminate work tasks in a clear and understandable manner.

This is where didactical principles can help (for example when learning police questioning and nurse injection procedures) demonstrate the pedagogical potential of using work tasks as a way that connects practical and theoretical knowledge. Students learn to justify the why and how around the work task. A work assignment often requires professional knowledge from several subjects in the programme. For instance, when the police student conducts questioning, he/she needs knowledge from ethics, law, communication, and psychology, all of which is aimed at the actual questioning methodology.

At the same time, there is a point during normal working processes that learning happens continuously in a colloquial setting, and it is important to recognize and emphasize this form of learning (Eraut, 2007). Additionally, there is often a need to acquire knowledge from various topics to learn the entire work process. Another point is that what students experience 
in education is insufficient to prepare them to meet the work life needs of competence if the practice in school does not vary in different practice or work tasks (Billett, 2010). Hence, we can see how important both theory and varied practice are, but these must become optimally integrated between the work task and the work context - which means coherence between relevant theory and practice.

Dewey's $(1895,1972)$ transaction theory focuses on a pragmatic comprehensive perspective in which the didactical categories are coherent with each other, as with the didactical relation model we used in the project. Considering this, there must also be coherence between knowledge and curriculum (Biesta, 2014). The results show the importance of a competencebased curriculum coherent with content, teaching and assessment methods, in order to achieve comprehensive professional competence. Wagner's (2008) research established that workplaces have already begun to seek other qualities than those schools are concentrating on.

According to both Wagner and the results of this project, it is necessary that the students develop competencies in innovating, creative problem solving, critical thinking, communicating and collaborating. It is therefore important for VET to focus on future workplace needs for competence. However, even if work life asks for more than mere instrumentalism, it is still important that VET is not solely based on what work life determines education should be (Young, 2004). Education and working life have different purposes. In addition to teaching skills and competences, education should also attend to the personal development of the students.

Wheelahan (2010) says that both practical and theoretical knowledge is important because the student also need for example, "sociological insights to understand how relations between educational institutions and families may be mediated by social class or ethnic background." This is important for adapting to both working life and society. Even so, I would still argue from these results that there is a need for job-relevant education to meet future workplace competency requirements in VET.

\section{Didactical Implications for VET}

Both society and working life are changing rapidly. There is a continuous need for further development of professional competence. This requires close cooperation and dialogue between educational institutions and workplaces to accommodate the need for both changing competence and specific professional competence (Billett \& Choy, 2013; Wagner, 2008). For both VET levels, these empirical examples of didactical principles of job-related VET are important for promoting the future work life needs of competence: 
- A key principle is the analysis of work tasks as a basis for curricula analysis and the planning of teaching by didactical relational thinking. This includes practical-theoretical planning of content, teaching and assessment related to a work context

- A competence-based curriculum is needed

- Coherence and comprehensive-professional competencies are essential

While coherence between theory and practice is widely accepted, it appears that learning comprehensive professional competencies is still fairly rare, especially in VET at the university level. This applies to both teaching and assessment activities. At the same time, participants in the study developed good didactical examples of relevant content, teaching methods and assessment, in which several students developed an incipient expert competence. This should be a goal for future VET. According to participants' experiences of some of their teacher/professor-colleagues, there are still teachers/professors who are not very concerned with or interested in job-related learning. This may due in part to a lack of tradition for jobrelated learning in VET, particularly at the university level. The results show a need for the development of professional didactical teacher competencies that focus on job-related VET as well. In addition, it is likely that other education programs may also benefit from the development of educational culture, curricula and didactical principles in both VET levels for meeting future workplace competency requirements.

\section{References}

Baartman, L., Gulikers, J., \& Dijkstra, A. (2013). Factors influencing assessment quality in higher vocational education. Assessment \& Evaluation in Higher Education, 38(8), 978-997. https://doi.org/ $10.1080 / 02602938.2013 .771133$

Biesta, G. J. J. (2014). Pragmatising the curriculum: Bringing knowledge back into the curriculum conversation, but via pragmatism. Curriculum Journal, 25(1), 29-49. https://doi.org/10.1080/095 85176.2013.874954

Billett, S. (2010). Learning through practice. In S. Billett (Ed.), Learning through practice: Models, traditions, orientations and approaches (pp. 1-20). Springer.

Billett, S. (2014). The standing of vocational education: Sources of its societal esteem and implications for its enactment. Journal of Vocational Education \& Training, 66(1), 1-21. https://doi.org/10.1080 $/ 13636820.2013 .867525$

Billett, S., \& Choy, S. (2013). Learning through work: Emerging perspectives and new challenges. Journal of Workplace Learning, 25(4), 264-275. https://doi.org/10.1108/13665621311316447

Canrinus, E. T., Bergem, O. K., Klette, K., \& Hammerness, K. (2015). Coherent teacher education programmes: Taking a student perspective. Journal of Curriculum Studies, 49(3), 313-333. https://doi. org/10.1080/00220272.2015.1124145 
Carr, W., \& Kemmis, S. (2005). Staying critical. Educational Action Research, 13(3), 347-358. https:// www.tandfonline.com/doi/abs/10.1080/09650790500200296

Cochran-Smith, M., \& Lytle, S. L. (1993). Inside/Outside: Teacher research and knowledge. Teachers College Press.

Dahlback, J., Olstad, H. B., Sylte, A. L., \& Wolden, A. C. (2018). Utfordringer og muligheter i møtepunktet mellom yrkesfaglærerutdanningen og pedagogisk praksis i videregående skole [Challenges and opportunities in the meeting point between vocational teacher education and pedagogical practice]. Nordic Journal of Vocational Education and Training, 8(3). 57-77. https://doi. org/10.3384/njvet.2242-458X.188357

Dewey, J. (1895). The theory of emotion. Psychological Review, 2(1), 13-32. https://doi.org/10.1037/ h0070927

Dewey, J. (1972). Plan of organization of the university primary school. In J. A. Boydston (Ed.), Early works of John Dewey (5th ed., pp. 224-43). Southern Illinois University Press.

Dreyfus, H. L., \& Dreyfus, S. E. (1986). Mind over Machine: The power of human intuition and expertise in the era of the computer. Free Press.

Elliott, J. (1991). Action Research for Educational Change. Open University Press.

Eraut, M. (2007). Learning from other people in the workplace. Oxford Review of Education, 33(4), 403-422. https://doi.org/10.1080/03054980701425706

Grimen, H. (2004). Samfunnsvitenskapelige tenkemåter [Ways of thinking in social research]. Universitetsforlaget.

Grollman, P. (2008). The quality of vocational teachers: Teacher education, institutional roles and professional reality. European Educational Research Journal, 7(4), 535-547. https://dx.doi.org/10.2304/ eerj.2008.7.4.535

Guile, D., \& Unwin, L. (2019a). Introduction to the handbook: Vocational Education and Training (VET) theory, practice and policy for a complex field of inquiry. In D. Guile \& L. Unwin (Eds.), The Wiley Handbook of Vocational Education and Training (pp. 1-39). John Wiley \& Sons.

Guile, D., \& Unwin, L. (2019b). VET, expertise and work: situating the challenge for the twenty-first century. In D. Guile \& L. Unwin (Eds.), The Wiley Handbook of Vocational Education and Training (pp. 19-40). John Wiley \& Sons.

Gulikers, J. T. M., Runhaar, P., \& Mulder, M. (2017). An assessment innovation as flywheel for changing teaching and learning. Journal of Vocational Education \& Training, 70(2), 212-231. https:// doi.org/10.1080/13636820.2017.1394353

Haight, A. (2012). "Hungry for Hands-on": Talented, inner-city engineering students, applied learning and employer engagement in a vocational-learning trajectory. Journal of Education and Work, 25(4), 381-402. https://doi.org/10.1080/13639080.2012.708724

Hattie, J., \& Timperley, H. (2007). The power of feedback. Review of Educational Research, 77(1), 81112. https://doi.org/10.3102/003465430298487

Hiim, H. (2010). Pedagogisk aksjonsforskning [Educational action research]. Gyldendal akademisk.

Hiim, H. (2016). Educational action research and the development of professional teacher knowledge. In E. Gunnarsson, H. P. Hansen, B. S. Nielsen \& N. Sriskandarajah (Eds.), Action research for democracy: New ideas and perspectives from Scandinavia (pp. 147-161). Routledge.

Hiim, H. (2017). Ensuring curriculum relevance in vocational education and training: Epistemological perspectives in a curriculum research project aimed at improving the relevance of the Nor- 
wegian VET. International Journal for Research in Vocational Education and Training, 4(1), 1-19. https://doi.org/10.13152/IJRVET.4.1.1

Hiim, H., \& Hippe, E. (2001). Å utdanne profesjonelle yrkesutøvere [To educate professional practitioner]. Gyldendal akademisk.

Hoskin, K., \& Anderson-Gough, F. (2004). The context of learning on professional work environments: Insights from the accountancy profession. In H. Rainbird, A. Fuller \& A. Munro (Eds.), Workplace learning in context (pp. 71-88). Routledge.

Kemmis, S. (2010). What is to be done? The place of action research. Educational Action Research, 18(4), 417-427. https://doi.org/10.1080/09650792.2010.524745

Lewin, K. (1952). Group decisions and social change. In G. E. Swansons, T. M. Netcomb \& F. E. Hartley (Eds.), Reading in Social Psychology (pp. 340-344). Holt.

Loo, S. Y. (2012). The application of pedagogic knowledge to teaching: a conceptual framework. International Journal of Lifelong Education, 31(6), 705-723, https://doi.org/10.1080/02601370.2012 .700649

McNiff, J. (2014). Writing and doing action research. Sage Publications.

Miller, G. E. (1990). The assessment of clinical skills/competence/performance. Academic Medicine: Journal of the Association of American Medical Colleges, 65(9), 63-67. https://doi. org/10.1097/00001888-199009000-00045

Ministry of Education and Research. (2008-2009). Læreren: Rollen og utdanningen [White paper on the teacher: The role and the education]. St.meld. nr. 11 (2008-2009). https://www.regjeringen.no/ no/dokumenter/stmeld-nr-11-2008-2009-/id544920/

Ministry of Education and Research. (2015-2016). Fag, fordypning, forståelse: En fornyelse av kunnskapsløftet [White paper on subjects, specialization, understanding: A renewal of knowledge-promotion].Meld. St. 28 (2015-2016). https://www.regjeringen.no/no/dokumenter/meld.st.-28-20152016/id2483955/

Patton, M. Q. (2015). Qualitative research \& evaluation methods. SAGE Publications.

Reason, P., \& Bradbury, H. (2008). Introduction. In P. Reason \& H. Bradbury (Eds.), The SAGE handbook of action research: Participative inquiry and practice (pp. 1-10). Sage Publications.

Schön, D. A. (1983). The reflective practitioner: How professionals think in action. Basic Books.

Smeby, J.-C. (2015). Academic drift in vocational education? In J. C. Smeby \& M. Suthpen (Eds.), From vocational to professional education (pp. 7-25). Routledge.

Smeby, J.-C., \& Heggen, K. (2012). Coherence and the development of professional knowledge and skills. Journal of Education and Work, 27(1), 71-91. https://doi.org/10.1080/13639080.2012.718749

Stenhouse, L. (1975). An introduction to curriculum research and development. Heinemann.

Sullivan, W. M. (2005). Work and Integrity: The Crisis and Promise of Professionalism in America (2nd ed.). Jossey-Bass.

Sullivan, W. M., \& Benner, P. (2005). Challenges to professionalism: Work integrity and the call to renew and strengthen the social contract of the professions. American Journal of Critical Care, 14(1), 78-80. https://doi.org/10.4037/ajcc2005.14.1.78

Sylte, A. L. (2014). Vurdering for yrkesrelevant opplæring [Assessment for relevant vocational education]. Nordic Journal of Vocational Education and Training, 4(1), 1-18. https://doi.org/10.3384/ njvet.2242-458X.14v4ila4

Sylte, A.L. (2015). Yrkesretting av teorien og yrkesdifferensiering - en vei for å hindre frafall ved yrkesopplæringen i videregående skole [Professional job-related theory and differentiation - a way 
to prevent drop-out in vocational education]. In O. Eikeland, H. Hiim \& E. Schwencke (Eds.), Yrkespedagogiske perspektiver (pp. 140-167). Gyldendal Akademisk.

Sylte, A.L. (2016). Profesjonspedagogikk - yrkesretting og profesjonsretting av pedagogikk og didaktikk [Professional pedagogy: Professional job-related pedagogy and didactic] (2nd ed.). Gyldendal Akademisk.

Sylte, A. L. (2018). Profesjonsretting og studentaktivitet [Professionalisation and student activity]. Scandinavian Journal of Vocations in Development, 3, 1-26. https://dx.doi.org/10.7577/sjvd.2694

Torrance, H. (2007). Assessment as learning? How the use of explicit learning objectives, assessment criteria and feedback in post-secondary education and training can come to dominate learning. Assessment in Education: Principles, Policy \& Practice, 14(3), 281-294. https://doi. org/10.1080/09695940701591867

Wagner, T. (2008). The global achievement gap: Why even our best schools don't teach the new survival skills our children need - And what we can do about it. Basic Books.

Wheelahan, L. (2010). Why Knowledge Matters in Curriculum: A social realist argument. Routledge.

Winch, C. (2010). Dimensions of expertise: A conceptual exploration of vocational knowledge. Continuum International Publishing Group.

World Economic Forum. (2018). The future of jobs report 2018. World Economic Forum. https://www. weforum.org/reports/the-future-of-jobs-report-2018

Young, M. (2004). Conceptualizing vocational knowledge: Some theoretical considerations. In H. Rainbird, A. Fuller \& A. Munro (Eds.), Workplace learning in context (pp. 186-200). Routledge.

\section{Biographgical Note}

Dr Ann Lisa Sylte, Associate professor at OsloMet - Metropolitan University, Faculty of Teacher Education and International Studies: Sylte teaches and supervises at the master's program in Vocational Pedagogic and at the $\mathrm{PhD}$ `s program, Educational Sciences for Teacher Education. She has extensive experience in teaching and supervision at Postgraduate Certificate Teaching in Professional Education and Vocational Teacher Education, as well as research work in Vocational and Professional Education. Sylte is also a research-group manager and project manager for a large action research project. Her research work focuses on relevant vocational and professional education such as didactical principles for vocational and professional orientation of content, working methods and assessment, as well as collaboration between universities, schools and working life. 